\title{
Duality in Robert Frost's Poetry: The Fusion of Tradition and Modernism
}

\author{
Han $\mathrm{Wu}^{1,2, *}$ \\ ${ }^{1}$ School of Foreign Language and Literature, Wuhan University, Wuhan, Hubei 430072, China \\ ${ }^{2}$ Faculty of Arts, The University of Hong Kong, Hong Kong 999077, China \\ *Corresponding author. Email: whango1999@163.com
}

\begin{abstract}
Amid the American modern literary circle, Robert Frost is honored as "American Poet Laureate" and is one of the greatest and the most popular poets. Based on the settings of New England, his poems that are fraught with idyllic scenery and his laboring experience are expressed through a comparatively traditional prosody. His unique writing technique and characteristic enable him to win more diversified audience since whether they are literary experts or demotic readers, they are capable to interpret the poems from dual perspectives of opaque modernism as well as a relatively more intelligible Victorian writing style. Upon this foundation, this article aims to discuss how this great luminary manages to organically amalgamate traditional form with modern ethos. In order to reach this purpose, the author will analyze the rhetorical device and connotation of some masterpieces of Frost, e.g., "Birches", "The Road Not Taken", "Fire and Ice", etc. to investigate the duality of tradition and modernism.
\end{abstract}

Keywords: Robert Frost, Modernism, Poetry, Contradiction, Literature study.

\section{INTRODUCTION}

\subsection{Research Background}

When an eminent literatus was venerated by coevals or even future generations, the audience were inclined to investigate the requisite reason for his or her accolade. For instance, Shakespeare, the illustrious playwright who gallantly broke Aristotle's "three unities", was still explicated and interpreted after the vicissitude of 400 years. Similarly, the epitome of American modern poetry and Pulitzer Prize winner, Robert Frost, was inscribed in every citizen's mind as a hoary sage gazing at the convulsion with his perspicacity and a tinge of melancholy. From the author's perspective, his eternal popularity is due to the duality between tradition and modernism, which is more like the notion of contradiction mentioned in Marxism than the simplified dichotomy in a narrow sense. The tension and fusion of dual power is undoubtedly pivotal to grasping the charisma of his poems, yet the majority of scholars, esp. in China, just focused on the specific techniques in his masterpieces instead of exploring the fundamental, ultimate pattern. He once dismissed the usage of footnotes in Collected Poems, Prose, and Plays since it "robbed the heart of chance to see for itself what a poem is all about" [1]. This opinion enables his poems to obtain greater possibility to be comprehended from diversified aspects. Hence, the aims are to probe into the relationship and doubleness between tradition and modernism in Robert Frost's poetry to unveil the approaches he utilized to erect his effulgent literary edifice.

\subsection{Literature Review}

As it has been said in the previous section, most Chinese scholars are inclined to select several his famous poems to analyze the themes or methods he employs or delineates most frequently. For instance, Wang $\mathrm{Lu}$, expounded the death wish in "Stopping by Woods on a Snowy Evening", manifesting the bleak side of this national poet's inner mind [2]. Likewise, many domestic scholars also focused on some specific approaches Frost has utilized to achieve his goal of conveying certain viewpoints to his audience. Wang Hong concluded that the unique sense of uncertainty portrayed in the 
majority of poems is displayed by rhetoric methods like his exquisite metaphor, specious paradox and multifarious peroration [3]. To comprehend Frost's approaches more narrowly and specifically, Tsui Weiqiao analyzed the contradiction and emphasis on individuality in "The Road Not Taken" and discussed the discrepancy between these two roads [4]. Wei Mengting coalesced Robert Frost's poetry with linguistic analysis such as Lakoff and Johnson's Conceptual Metaphor Theory (CMT) as well as Fauconnier's Conceptual Integration Theory (CIT) [5]. Fu Xiaona published the article to explicate his idea of transcendentalism and philosophical dualism between people and society, which is an extremely inspiring research since she also discovered the doubleness in his poetry even though the dominant focuses are dissimilar [6].

Amid the foreign study of Robert Frost, many scholars tried to discover the general patterns of his works. For example, in some more previous studies antecedent the $21^{\text {st }}$ century, foreign scholars are likely to choose one poem and analyze it exhaustively. Firstly, life study is pivotal in reviews of this national poet. The prevalent pioneer of this kind of research is Lawrance Thompson who spent ten years to write three-volume biography of Robert Frost and make indelible contribution to Frost's biographical study [7]. Though his work riffled both positive acclamation and negative criticism, it was undoubtedly conducive for literature learners to grasp a holistic view of Frost. On the contrary, Jay Parini, another expert who wrote Robert Frost: A Life, was presently the most distinguished biographical writer of Robert Frost since his expression was far more objective than Thompson [8]. The most recent achievement of Robert Frost was the book The Cambridge Companion to Robert Frost (CCRF), edited by Robert Faggen [9]. This authoritative literary review encompassed twelve academic articles that discussed his works from political, ethical, historical and cultural angles. These eminent articles were accord with contemporary literary theories and criticism, which to some extent, has then guided the study of Robert Frost to a substantially higher level either from breadth and depth. Therefore, this article will select a rather broad yet highly original perspective to expound Frost's poems, which is the tension and fusion of tradition and modernism. Nevertheless, it will also winnow the advantage out of researches of domestic experts, such as the elaborate analysis of famous masterpieces of Frost.

\subsection{Brief Introduction of Frost}

Robert Lee Frost (March 26, 1874 - January 29, 1963) was an American poet whose works had been published in England before it was disseminated extensively in American literary circle. His realistic delineation of rustic life in New England has rendered him famous during the early 20th century. Amid this setting of agrarian life, Frost endeavored to explore the answers of philosophical and social dilemmas existed in his era. His simple diction and profound themes enabled him to win four Pulitzer Prizes for Poetry, Congressional Gold Medal and be named as the poet laureate of Vermont.

In his early years, Frost's father deceased tragically when he was 11-year-old. The constant moving from one place to another became the routine of his childhood. Then, in the rural area of the US, he participated in different kinds of jobs, from teacher, farmer to mill worker. This experience of laboring engendered his unique insight towards labor and rustic lifestyle, distinguishing him from those avant-garde artists who pursued advanced modernism. His genuine calling was poetry and he has been writing poems in his spare time, which then been composed in his famous works A Boy's Will and North of Boston. Published in Great Britain, he made some important acquaintances like Pound and Edward Thomas who proffered great help in his later literary career. Admittedly, his professional success was unassailable, yet his unusual longevity in that turbulent era presaged the fact that he had to encounter the miserable loss of the beloved ones. His life was plagued with deaths and mental illness of family members, including his mother, sister, wife and four of his children. This dolorous fact made his poetry be infused with melancholy, yet in the end, there was always strong hope under the seemingly grieved sentences.

\section{TRADITIONAL FORM}

\subsection{Metrical Analysis}

Being an immensely skillful and industrious poet who always accentuates a rather traditional kind of versification, Robert Frost is quite idiosyncratic during the modern era. Though his technique of creation and unique versification are saturated with his own inimitable characteristics, the metrical analysis of Frost's poems is scarcely mentioned amid the circle of expertise. Yet from the author's perspective, language learners should 
be firstly acquainted with meters and metrics before moving on to the next step like exploring the theme and social context of a poem.

It seems that expounding the versification is one of those monotonous chores in literature studies, but that of Frost's is entirely different since his prosody is filled with variety and moderation. Firstly, his language contains verse, prose and novel, from lyric to narrative, which is like the encyclopedia of poetry. Not only does he display the diversification in genres of poems, he also adds innovation into the tradition of meter and rhythms. Instead of adhering to rules and forms established by forbears, he does not replicate the uniform fluctuation in every sentence. Syllables do not fall neatly into the minimum or the maximum accent, rather, it is sometimes more emphatic or less. For instance, Line 11 in "Hyla Brook" says that "Of dead leaves stuck together by the heat." According to the regulation in iambic pentameter, the underlined parts should be stressed, yet the degree between "by" and "heat" are undoubtedly different. Another example of variety is that he amalgamates some dynamic syllables into the traditional blank verse. The first line in "Birches" is one of them since it says that "When I see birches bend to left and right". Normally, in regular iambic pentameter, we should not emphasize "see" for it encounters the first syllable of "birches". Nonetheless, when we read the sentence, we may unconsciously stress "see" because it is a notional word. Hence, he furnishes variety into tradition and renders it more interesting and inspiring.

Secondly, his poetry demonstrates a sense of moderation since he spurns absolute rigidity in forms and also dismisses the free verse endorsed by modern poets who pursue liberty in expression. Due to the fact that Frost always acclaims how meter and rhythm form a harmonious entity with each other, he is rather skeptical about poets who disdain traditional forms. He commented on Pound that "Ezra Pound used to say that you've got to get all meter out of it. If you do, you've got true free verse, and I don't want any of it! [1]" As his audience, personally speaking, I concede that Pound and Eliot are Frost's conscientious contemporaries, yet I also espouse Frost's attitude towards tradition of poetry for his poems are much more readable than arcane allusions with scarce prosody written by avant-garde poets. On the other hand, he also criticizes people who merely hanker for prosodic exactitude and want to coerce the variable rhythms. Therefore, by furbishing variety of genres and syllables into poems that created along with traditional rules, Frost has achieved the sense of moderation that should be treasured in modern poetry. His poems neither replicate classical prosody entirely, nor eschew the aesthetic standard of tradition, and ultimately form the unique style that speech could vitally coexist with normative metrics.

\section{2 "The Sound of Sense"}

People might be skeptical about the category of "the sound of sense" in this article for, it should be subsumed as the innovative notion Frost has proposed in his approach of modernism. Yet this prevalent concept invented by Frost reminds me of western bards and Shi Jing (The Book of Songs) in China from the archaic time. In retrospect, poetry was chanted by progenitors after grueling labor so as to entertain or to sacrifice. Although "the sound of sense" is treated as a novel and original idea, it is actually a "renaissance" to guide readers and scholars to consider the preliminary function of poetry, which is something to say, sing, declaim or simply read aloud.

The definition of this principle is rather abstract and there are no specific words to depict this term in his formal essays. Nonetheless, the meaning is quite intelligible for us, which is the power of vocal tone to convey meaning in addition or independent of diction. In other words, the sound itself in poems can make sense. In Frost saying is that "it is the abstract vitality of our speech; it is the pure sound-pure form." The reason why he loves the sound and colloquial language as a whole is that he probably favors human voice as he wrote in 1915 that "I like the actuality of gossip, the intimacy of it [1]." Thus, due to his accentuation on sound or voice, his strong predisposition to easy vocabulary and colloquial expression is comprehensible. Unlike late-Victorian poet Tennyson, his style is against the exceedingly mellifluous language, which is similar with coeval poets like Pond, Yeats and Eliot. But different from them, Frost pursuits a simpler yet more beautifully refined colloquial language instead of some complex allusions and quotations. Therefore, his language is easy to read for all people but it is truly hard to interpret.

In poems like "Mowing" and "Stopping by Woods on a Snowy Evening", Frost employs the previous concept. By utilizing some unique qualities of certain sounds, he creates a vivid scenery according to the content. For instance, in "Mowing", he uses abundant /s/ and /w/ sounds to depict delicate and quiet noise in this laborious 
process. In the poem, audience can see some obvious words that embody the "sound of sense", like "sound", "wood", "whisper", "scythe", "sweetest" and so on. These consonants have undoubtedly guided audience to the working place where people can relish the monologue of the mower in serenity. He also deliberately uses the words like "perhaps" and "something" to emphasize the calculated vagueness generated by the tool.

Likewise, /s/, /w/, /t/ and /d/ sounds are excessively employed in "Stopping by Woods on a Snowy Evening". Sounds /s/ and /w/ symbolize the noise of wind and snow, such as words like "stop", "sleep", "some", "snow", “wind", "woods", "watch" and "will", etc. Sounds /t/ and /d/, on the other hand, represent the sound of horseshoe in this snowy weather, such as words like "it", "must", "without", "deep", "dark" and "downy", etc. These sounds have lucidly delineated the protagonist is facing the difficult dilemma in his life. Therefore, by using simple words that encompass certain sounds, this concept, "the sound of sense", is the tribute to the rudimentary function of poetry and can truly bring us to the exact scene depicted by Frost.

\section{MODERN SPIRIT}

The lines within a late poem, "A Masque of Mercy", says that "Some people do not want you to understand them/ I want you to understand me wrong," a statement that is congruent with Robert Frost's own poetic practice [9]. And the majority of readers were not capable of recognizing the deeper truth concealed under the colloquial speech. Yet in retrospect, as a former laborer growing in the rustic place, Frost has created poetry that embodies profound implication concerning tools, labor and death.

In Frost's early years at the Arlington mills, he has witnessed and participated in the laboring process, which is a significant theme in his poems. Frost wrote abundant poems about laboring process as a nascent poet in his youth, one of them being "When the Speed Comes". This poem depicts those agile female workers who were doing the onerous task in the mill: "Unwilling is the flesh, the spirit weak,/ All effort like arising from the dead./ But the task ne'er could wait the mood to come,/ The music of iron is the law." In "The Mill City", he also writes solemnly: "Then back at night, like drowned men from the sea,/ Up from the mills and river hurriedly,/ In the weed of labor, to the shriek of steam." His themes of labor involve different types of laborer, such as the mower in the harvesting field, the lone striker who yearns for equal right, the spinner in humid rooms who are extremely vulnerable to tuberculosis, the self-seeker whose legs are crushed in a huge machine. Although it is too judgmental to conclude that the topic or the peroration of labor in Frost's poetry is proletarian, his compassion and emphasis towards laboring process and laboring people is unassailable. Not all of his poems concerning labor are pessimistic or critical, and the majority of them are objective, just conveying his understanding and misgivings for their lives in mills. But one thing can be certainhis New England and the related agrarian life is far from an idealistic utopia, rather, it is filled with sweat and struggle, only leaving readers images and suggestions instead exclusive statements.

Besides the accentuation of labor, the idea of tools is a fundamental symbol in his works since it externalizes and dominates human's will and relationship with this world. In the masterful poem, "Mowing", the long scythe "(is) whispering to the ground". Undoubtedly, like the former sections have explicated this poem, this poem is a monologue of a mower, a song of a solitary worker or a long sigh towards labor. Via the scythe, which is an essential and helpful tool, the speaker is able to build his relationship with this world because he utilizes the tool to construct things and realize his self-value. In the process of gaining fulfillment, the scythe, a conventional image in pastoral scenery, also plays the role of a quiet yet infelicitous weapon, cutting the grain ruthlessly in the whispering sound of "swale-swale". For those cereals on the ground, this delicate action is fearful and forceful, the tool owning double identities for human and the object. Hence, the tool cultivates in the process of haying, and yet in the meanwhile, it has an undoubtedly destructive motion for the grass or cereals. If the demolition of the tool is not that perceptible in this poem, it will be fairly evident in poems like "Out, Out-". With the malicious "snarls and rattles", the chainsaw in the boy's backyard leaps up the air and cuts the boy's hand and directly leads to his miserable death. Therefore, not only the grass can be killed by the tool, human's ephemerality and fragility in this infinite, almighty universe has rendered us be subject to mortality. The tools here are represented as time and death that every individual is destined to encounter, imposing the will of this cruel and bleak society. So, the tool, an aspect of the objective 
world, can incarnate and more dreadfully, manipulate human's limited will.

Due to the fact that physical labor is an essential part in Frost's growth, it is natural to compare his experience of physical labor and mental production. For Frost, the creation of poetry is resembled to that of manual work. For instance, as we all acknowledge that mowing or haying is an aspect of pastoral labor, which might lead the mower to ruminate or fantasize about certain things. The former paragraph has explained that "Mowing" is a song of a solitary worker who is doing his chores while pondering on the sound of the scythe's whisper. Nonetheless, just like every other poem of Frost, almost everything in Frostian poems is figurative and metaphoric. This poem, as far as I am concerned, not only implies the speaker's emotion of idle hours in noontime, but also suggests Frost's insight of writing poems, which is a kind of divine spiritual labor. There is "no dream" or "easy gold" in physical labor as well as in mental production. The phrase "laid the swale in rows" is similar with the act of combining different words into sentences in poems and arranging sentences into poems or broadly, discourses. The line "the fact is the sweetest dream that the labor knows" demonstrates his perspective or ideal of literary creation, which is to base on the reality and truth. Thus, he claims "anything more than the truth would have seemed too weak," indicating his antipathy towards the ostentatious inflation and excess of the real world.

The poem "Birches", like "Mowing", also explicates metaphorically Frost's idea of creating poems. The image of birches is the play tool for the boy, transcending the innate limit of the body and facilitating him to reach a higher position. For Frost, his birch is poetry, which is resembled to an intangible tool for him to express, explain and explore himself. Like I have analyzed previously, the tool in Frostian poems is not absolutely secure and impeccable, rather, it is perilous and precarious for it represents the will of the enigmatic objective world. Therefore, though birches are sufficiently high to ascend the boy to the euphonious heaven as it has depicted in the poem, the boy is still manipulated by the hazardous gravity and the tree could probably "bear no more". This phenomenon recalls me the Greek mythology of the dolorous over-reacher, Icarus, whose wings melted when he endeavored to fly out the maze and approach the sun. For Frost, admittedly, he yearns to challenge himself in his dedicated and prolific career, yet on the other hand his tragic experience of the huge loss of family members, friends and many other rapports might render him to contemplate the justice of God besides his eclat he has received. Ultimately, the speaker decide to come back the earth by explaining "earth's the right place for love". The playful swinging has stopped and the poem has terminated as if it represents Frost's will to continue his life gallantly instead of indulging himself in beautiful hallucination. In my opinion, the earth, in the metaphorical meaning, also refers to the tradition, or more narrowly, the classical form for his creation. Like the boy, he desires for the breakthrough, "to climb high toward heaven till the tree could bear no more", yet different from some radical modern poets who always write "incomprehensible" words to present their erudition, he still regards the tradition as the fundamental basis for creating novel ideas or insights as he wrote "I'd like to get away from earth awhile and then come back to it and begin over."

In conclusion, on account of the frequent association with laboring process for Frost, he accentuates the physical work in his poem and substantiates his compassion towards those workers in Arlington mills. Additionally, the emphasis of tool in his lines manifests the double identities of tool, which are the conducive and malicious aspects. It can either assist human to cultivate and fulfill their value, or it symbolizes the cruel and objective world where human's will is quite limited and all individuals are subject to death. Besides the themes of physical labor and the duality in tools, Frost opines the mental production, the process of creating poetry, is resembled to physical labor. His ambition is to challenge himself by exploring and ascending to a much higher level. Yet he also wishes to conform to the rules while being innovative in his insights he would like to convey to readers.

\section{THE FUSION}

As the topic of this article suggests, the tension and fusion of his traditional form and modern thinking is the seminal part of our discussion. It seems like an arcane topic, yet if we have already analyzed these two essential terms of tradition and modernism, it will be lucid for us to comprehend the fusion since it mainly expounds how tradition and modernism contradict and merge with each other. Therefore, the following paragraphs will fully illustrate the notion of fusion in details.

The fusion of classical form and modern spirit firstly breaks down the barrier of prejudice 
regarding the narrow sense of tradition and modernism. In order to aid students in understanding different literary movements and criticism, Chinese teachers might often use the exact timeline for memorizing. Though it is definitely efficient to grasp the essence of diversified theories and genres, this rote learning is also didactic and unconsciously leads to staid idea of various theories. The modernism is misconstrued as something inscrutable and absurd, accentuating human beings' defective characters like cowardice, avarice and eternal alienation in relations. Although Frost has been categorized as modern poet, he still bases his poems on rural areas and conforms to traditional rules like iambic pentameter, blank verse, regular rhythms and emphasis on sounds. These qualities render his poems popular because they are apposite for demotic culture and literacy. Amid his poems, characters are not flat or simply classified as good or evil, on the contrary, they are complicated individuals and sophisticated interlocutors who have different personalities. These features evince the fusion is rather successful in neutralizing the barriers and stereotypes of tradition and modernism.

The coalition of tradition and modernism also galvanize the poet's innovation, so as to inscribe deeper influence on readers as well as the literary field. People might assert that some writing techniques in modernism should be considered as creative and insightful, like Woolf's and Joyce's stream of consciousness. Admittedly, they have invented a novel way to express the alienation and other emotions of modern beings. Yet I still opine that the accentuation of classics and tradition in modern era is also a kind of innovation in a reversed direction. The small-scale renaissance to traditional form is probably a haven for those confounded readers rambling the maze of modern literature. This creative fusion that combines two opposite trends has undoubtedly facilitated audience in acknowledging the essence of modernism, which proffers a platform of peace and order in the chaos of absurdity. Frost commented on poetry as creating "a momentary stay against confusion", thus he likes employing simple diction that everyone could apprehend literally. And "the sound of sense" is a huge salvation for readers to relish an aural feast in the palace of literature, giving us many "eureka moments". Different from Pound and Eliot, his fusion of traditional diction and modern insight offers readers repose or recreation, saving us from endless allusion and unrhymed sentences, which is a temporary shelter for readers to concentrate on the words and sounds themselves. Moreover, not only can the audience discover the order and tranquility of tradition in the modern era, they can also find the advanced and progressive ideas under the traditional forms. Frost admits the function of poem is transient, hence he endeavors to explore the root of the paradox with his lines, which is a higher level of transcendentalism in secular settings. For the simplicity of his vocabulary and grammar, it is a shame and pity for readers to be oblivious of the underlying meaning of his sentences. Truly, people are fascinated by the rustic life he has depicted in the superficial facet, and fewer and fewer people can challenge to keep up with him or engender spiritual empathy, just like many people are unaware that he has extensive knowledge of philosophy, astronomy and Darwinism. This plangent fact leads me to cherish the epiphany I have obtained in this poetry even more.

In summary, the fusion of these terms in his poetry has already broken down stiff boundaries and rooted stereotypes between tradition and modernism, thus it can convey Frost's own innovation and the distinguish him from other poets.

\section{CONCLUSION}

By analyzing Robert Frost's works exhaustively in previous chapters, it has been concluded that his enormous success in literary field is closely correlated with the duality of traditional form and modern implications. The fusion of these terms breaks the bias and barriers of tradition and modernism, demonstrating his masterful innovation. Perusing his poems diligently, the author eschews the defect of some domestic researches that merely concentrate several famous poems of Frost in order to explicate his writing skills, rather, she pursues the integrity and comprehensiveness of the study by delving into the essence of Frost's writing patterns and his own insight. Different from the rigmarole of praising his simplicity in expressing and conveying his opinions, the author discovers the duality between tradition and modernism, which is extremely pivotal in apprehending his idea towards poetry and literature. In the part of tradition, the author traces back to the origin of traditional forms like iambic pentameter, blank verse and rhythms to inspect the prosody of Frostian poems. Then, the chapter also focuses on the theory postulated by Frost, the famous "sound of sense", which embodies Frost's 
emphasis of aural effects of the diction and sentences. In the section of modernism, the author mainly discusses the implications of labor, tool and death in the themes of the poetry. In this aspect, Robert Frost has infused many creative as well as advanced ideas like equality in workplace, fragility of human being and his ambition in writing. Finally, the chapter of fusion concludes the effect of this duality, acclaiming his innovation from a broad sense.

\section{AUTHORS' CONTRIBUTIONS}

This paper is independently completed by Han $\mathrm{Wu}$.

\section{REFERENCES}

[1] P. Richard, \& R. Mark. Collected Poems, Prose and Plays. New York: Library of America, 1995, pp. 809-820.

[2] W, Lu. "A death wish in 'Stopping by Woods on a Snowy Evening,," in Central China Normal University Journal of Postgraduates, vol. 26, pp. 1-6, January 2019.

[3] W, Hong. "An interpretation of the uncertainty in Robert Frost's poetry," in Literary Education, vol. 3, pp. 4-8, August 2009.

[4] T, Weiqiao. "The paradox in 'The Road Not Taken'," in Journals of Wenzhou University, vol. 22, pp. 10-13, April 2019.

[5] W. Mengting. “Analysis of Robert Frost's metaphor and construction of Conceptual Metaphor Theory," in Literary Education, pp. 24-28, November 2019.

[6] F. Xiaona. "Transcendentalism and dualism: philosophical analysis on Robert Frost's poetry," in Shanghai Foreign Languages University, 2003.

[7] T. Lawrance. Robert Frost - The Early Years, 1874-1915. New York: Henry Holt and Company, 1966.

[8] P. Jay. Robert Frost: A Life. London: Picador, 2000.

[9] F. Robert. The Cambridge Companion to Robert Frost. Shanghai:Shanghai Foreign Education Press, 2004, pp.4-16. 